\title{
Gongola Basin Geoid Determination using Isostatic Models and Seismic Reflection Data and Geophysical Interpretation
}

\author{
(C) E. E. Epuh, J. B. Olaleye, O. G. Omogunloye, 2016 \\ Department of Surveying and Geoinformatics, University of Lagos, Nigeria \\ Received September 9, 2016 \\ Presented by the Editorial Board Member V. I. Starostenko
}

\begin{abstract}
Применение формулы Стокса для вычисления ундуляций геоида требует отсутствия масс вне его. Как правило, постоянная плотность 2,67 г/см³ используется при определении геоида, что обусловливает ошибку в редуцированных гравитационных аномалиях (конденсация Гельмерта) и, следовательно, геоида. В работе использованы изостатические модели Эри-Хейсканена и Пратта-Хейфорда при определении геоида, рассматривая приближенные плоские и сферические модели. Рассчитан непрямой эффект изменения топографической латеральной плотности на геоиде в качестве аддитивной поправки для улучшения точности вычисленного геоида. Аля расчета переменной плотности рассмотрена дополнительная информация о плотности, полученная по сейсмическим и каротажным данным. По модели EGM 2008 рассчитаны геопотенциальные ундуляции геоида. Остаточный геоид получен путем вычитания локального изостатического геоида из геопотенциального геоида. Также проведены исследования проводимости геоида и гравитационного поля в дополнение к изучению остаточного геоида.

Планарная и сферическая аппроксимации показали сходные характеристики, но с разными величинами в обеих моделях. Наши результаты свидетельствуют о том, что эффекты латерального изменения топографические плотности при определении геоида являются значительными и должны рассматриваться в рифтовых бассейнах. Геофизический анализ результатов определения геоида показывает, что северо-восточный регион имеет положительные значения остаточного геоида, которые указывает на наличие интрузивных магматических пород высокой плотности, тогда как юго-западный имеет отрицательные величины остаточного геоида, что свидетельствует о доминирующем присутствии осадочных пород низкой плотности. Результаты также показывают, что радиальное распределение аномальной массы, полученное при использовании аномалий геоида/остаточного геоида, однозначно соответствует полученному распределению с использованием данных сейсмического профилирования методом отраженных волн, которые обнаружили скопления углеводородов в юго-восточной зоне на территории проекта. Исследования проводимости гравитационного поля и геоида подтвердили результаты изучения остаточного геоида и сейсмических наблюдений.
\end{abstract}

Ключевые слова: ундуляции геоида, модель Эри-Хейсканена, модель, Пратта -Хейфорда, изостатическая остаточная аномалия силы тяжести, остаточная ундуляция геоида.

\subsection{Introduction}

Topographical effect is one of the most important components in the solution of the Geodetic Boundary Value Problem (GBVP), and should be treated properly in the determination of a precise geoid. The classical solution of the geodetic BVP using Stokes's formula for geoid determination assumes that there should be no masses outside the geoid. The input gravity anomalies should refer to the geoid, which requires the actual Earth's topography to be regularized in some way. The determination of the geoid as an internal geodetic boundary value problem is described by [Heck, 1992; Moritz, 1980]. There are different reduction methods depending on the way in which these topographic masses are dealt with [Heiskanen, Moritz, 1967, p. 126-158]. One of such methods used is the topographic isostatic reduction. Recent studies along the line of geodetic isostacy include [Rummel et al., 1988; Engels et al., 1995; Tsoulis, 2001, 2003a,b; Claessens, 2003; Kuhn, 2003; Wild, Heck, 2004a,b; Kaban et al., 2004; Heck, Wild, 2005]. The basic concept of isostacy assumes that the outer masses of the earth down to a certain compensation depth are in hydrostatic equilibrium with the masses below [Kuhn, 2003]. According to topographic isostatic reduction, the topographic masses are not completely removed, but are shifted 
into the interior of the geoid [Heiskanen, Moritz, 1967] Until now, the common practice in geoid determination has been the application of a crustal density of $2.67 \mathrm{~g} / \mathrm{cm}^{3}$ for the topographic masses [Vanicek, Kleusberg, 1987; Featherstone, 1992; Forsberg, Sideris, 1993; Abd-Elmotaal, 1999; Smith, Milbert, 1999; Featherstone et al., 2001]. However, the real density can differ from this value by $10 \%$ or more [Martinec, 1993; Tziavos et al., 1996; Pagiatakis, Armenakis, 1998; Kuhn, 2000a,b; Huang et al., 2001]. While sedimentary rocks often have density values below $2.40 \mathrm{~g} / \mathrm{cm}^{3}$ mafic igneous and plutonic rocks have density values above $3.0 \mathrm{~g} / \mathrm{cm}^{3}$. Martinec [1993] showed theoretically that small lateral density variation of topographic masses may introduce errors on the geoid height of more than one decimeter.

Fraser and colleagues have developed a GIS based system to calculate terrain corrections using the real topographical rock density values [Fraser et al., 1998]. The results show that in the Skeena region of British Columbia Canada, the terrain corrections to gravity can change by a few mGals when real topographical density is used. Further, [Pagiatakis et al., 1999] showed that the effect of lateral density variations on the geoid can reach about $10 \mathrm{~cm}$ in the Skeena region and several millimeters in New Brunswick, where the terrain is moderate. Also, [Sjöberg, 2004] showed that the total effect on the geoid from lateral density for the deepest lake on Earth (Lake Bajchal) and the highest mountain on Earth (Mt. Everest) can reach up to $+1.5 \mathrm{~cm}$ and $+1.78 \mathrm{~cm}$ respectively. These differences are the reason for using improved density model in geoid determination based on Stokes' function [Kuhn, 2003]. Several studies have previously investigated the use of lateral varying topographic density models in gravimetric geoid determination (e. g. [Martinec et al., 1995; Marti, 1997; Kuhtreiber et al., 1998; Pagiatakis et al., 1999; Tziavos, Featherstone, 2000; Haung et al., 2001; Hunegnaw, 2001; Kiamehr, 2006a,b]). In the Nigerian geoid determination [Nwilo et al., 2007] modeled the local geoid of Lagos (Nigeria) based on geometrical interpolation approach. By using the orthometric height and ellipsoidal height, the empirical geoid height were computed. The surface interpolation utilized the kriging approach. Isioye and colleagues utilized a five to eight parameter model to fit the GPS/Leveling to the EGM 2008 model to improve the determination of orthometric height observed from GPS in the study area (Portharcourt, Nigeria) [Isioye et al., 2011]. Ezeigbo and colleagues examined some factors that affect the accuracy of gravimetric geoid determination us- ing mean gravity anomalies over geographically defined grids [Ezeigbo et al., 2007]. Gravity anomaly data obtained from satellite altimetry mission were used in the evaluation of the Stokes' and Vening Meinesz's integral formulae. The result shows that the most significant parameters that affect the accuracy of gravimetric geoid determination are the minimum spherical distance from the computation point, the size and distribution of the observed gravity anomaly data. Okiwelu and colleagues determined geoid undulation for Nigeria using the spherical harmonics expansion employed in the Earth Gravitational Model 2008 (EGM 2008) referenced to the WGS 84 (World Geodetic System 1984) [Okiwelu et al., 2011]. In their study, they found that the highest geoid undulations are centered over the North Central region of Nigeria with relatively lower values (16-20 m) confined to the Nigerian sedimentary basins (Bornu basin and Benue Trough). In this study, the Pratt-Hayford and Airy-Heiskanen isostatic models as well as density data derived from seismic and well log observations (Kolmani River-1 log) will be utilized in the determination of the geoid. The main advantage of using isostatic models in geoid determination is their small indirect effect, together with a smooth field of gravity anomalies [Kuhn, 2003[. Isostatic geoid are also long wavelength in nature and as such are dominated by the signature of deepmantle anomalies (e. g. [Hager, Clayton, 1989]) and/or subducted slabs (e. g. [Ricard et al., 1993]). The introduction of the additive lateral density variation indirect effect and the primary indirect effect terrain effects will improve the accuracy of the computed geoid and hence, the accuracy of the interpreted geophysical structures.

Variations in the height of the geoidal surface are related to density anomalous distributions within the Earth and the geoid undulations help to understand the internal structure of the earth. Fig. 1 [Lowrie, 2007] shows that positive geoid indicates the presence of high density excess mass, while negative geoid indicate regions of mass deficiency or low density mass deposits. The use of geoid in geophysics has been presented by [Vanicek, Christou, 1994; Featherstone, 1997] in which; the relationship between the geoid and deep Earth mass density anomaly structure, strain and stress fields, tectonic forces, isostatic state of ocean lithosphere, Earth rotation, geophysical prospecting and ocean circulation are discussed. However, the importance of geoid in the determination of the anomalous density distribution has also been recognized by [Kaula, 1967; Chase, 1985; Lambeck, 1988]. Brown in his work [Brown, 1983] recognized 
the correlation between the geoid and the deepEarth mass density anomalies; while [Christou et al., 1989] showed its correlation with near surface mass density anomalies. Also correlations between geoid and earth mantle convection is established by [Runcorn, 1967] and with plate tectonic features and seismic tomography by [Silver et al., 1988]. Featherstone used geoid to determine the lateral extent of known geological structures [Featherstone, 1997]. The geoid approach in this research, serves as a complementary way of studying the earth interior and mass density distribution in the Gongola basin. Most previous studies have relied heavily on geophysical approach; for example [Okereke, 1988; Osazuwa et al., 1992; Ugbor, Okeke, 2010; Okiwelu et al., 2010; Okiwelu et al., 2011].

\subsection{The Isostatic Models}

\subsection{Airy-Heiskanen Model (Planar and} spherical approximation)

The model is applied under the following assumptions [Rummel et al., 1998; Kuhn, 2003; Ilk, Witte, 2007] that the isostatic compensation takes place completely and locally, i.e. the compensation mass is directly under the regarded topographic mass which makes the compensation depth variable (Fig. 2).

The root thickness $t$ for planar approximation is obtained by [Heiskanen, Moritz, 1967; Grant, West, 1987] as:

$$
t_{p}=\frac{\rho_{\mathrm{cr}}}{\Delta \rho} H
$$

where $t_{p}$ - root thickness (planar), $\rho_{\text {cr }}$ - crustal density $\left(2.67 \mathrm{~g} / \mathrm{cm}^{3}\right), \Delta \rho$ - the variable density contrast between the lower crust and the upper mantle, $H$ - topographic height.

The root thickness $t_{\mathrm{sp}}$ for spherical approximation is obtained by [Rummel et al., 1998; Ilk, Witte, 2007] as

$$
t_{\mathrm{sp}}=(R-T)\left[1-\sqrt[3]{1-\frac{\left((R+H)^{3}-R^{3}\right) \rho_{\mathrm{cr}}}{(R-T)^{3} \Delta \rho}}\right],
$$

where $R$ - radius of the earth $(6371 \mathrm{~km}), T$ - normal thickness.

Usually it is applied assuming:

- a constant compensation depth (D) of $100 \mathrm{~km}$ at which the hydrostatic equilibrium is achieved;

- that due to constant compensation depth, the condition of equilibrium leads to a laterally variable mass density. Fig. 3 illustrates the Pratt-Hayford model.

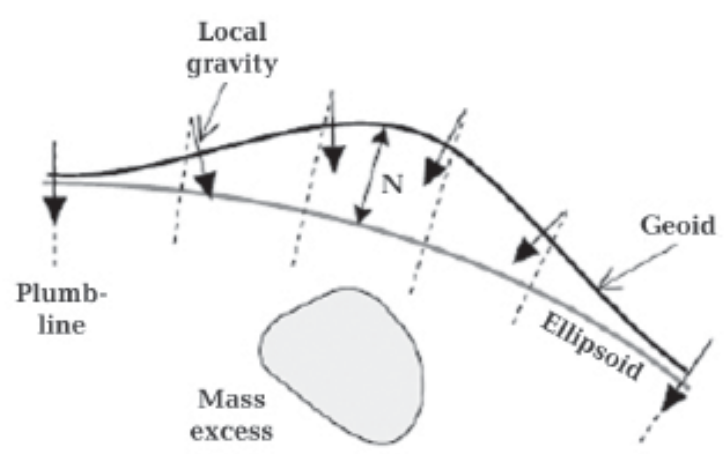

Fig. 1. A mass excess below the ellipsoid elevates the geoid above the ellipsoid. $\mathrm{N}$ is the geoid undulation [Lowrie, 2007].

The variable density for the planar model is expressed as:

$$
\rho_{\mathrm{L}_{\mathrm{p}}}=\frac{D}{D+H} \rho_{\mathrm{cr}}
$$

$\rho_{\mathrm{L}_{\mathrm{p}}}$ - density variation on land (planar), $D-$ depth of compensation on land (100 km), H topographic height on land.

For spherical approximation, $\rho_{\mathrm{L}_{\mathrm{p}}}$ is given as [Rummel et al., 1998; Ilk, Witte, 2007]:

$$
\begin{gathered}
\rho_{\mathrm{L}_{\mathrm{sp}}}=\rho_{\mathrm{cr}}- \\
-\frac{H}{D}\left[1+\frac{H+D}{R}+\frac{(H+D)(h+2 D)}{3 R^{2}}\right] \rho_{t},
\end{gathered}
$$

$\rho_{\mathrm{L}_{\mathrm{sp}}}$ - density variation on land (spherical), $\rho_{t}$ - weathered tertiary density value, $R$ - radius of the Earth.

\subsection{Spherical Harmonics Representation of} Geoid

Spherical harmonics are often used to approximate the shape of the geoid. The geoid undulations are evaluated from spherical harmonic coefficients at the surface of the ellipsoid, not taking into account the difference between height anomalies and geoid undulations [Heiskanen, Moritz, 1967, p. 325] nor the effect on the geoid of the downward continuation of gravity from the surface [Sjöberg, 1998a; Kaban et al., 2004]. Geoid undulation $(N)$ can be expressed in spherical harmonics as [Rapp et al., 1991]:

$$
\begin{gathered}
N=\frac{G M}{r \gamma}\left(\sum _ { n = 2 } ^ { N } ( \frac { a } { r } ) ^ { n } \sum _ { m = 0 } ^ { n } \left(\bar{C}_{n m} \cos m \lambda+\right.\right. \\
\left.+\bar{S}_{n m} \sin m \lambda\right) \bar{P}_{m n} \sin \varphi .
\end{gathered}
$$




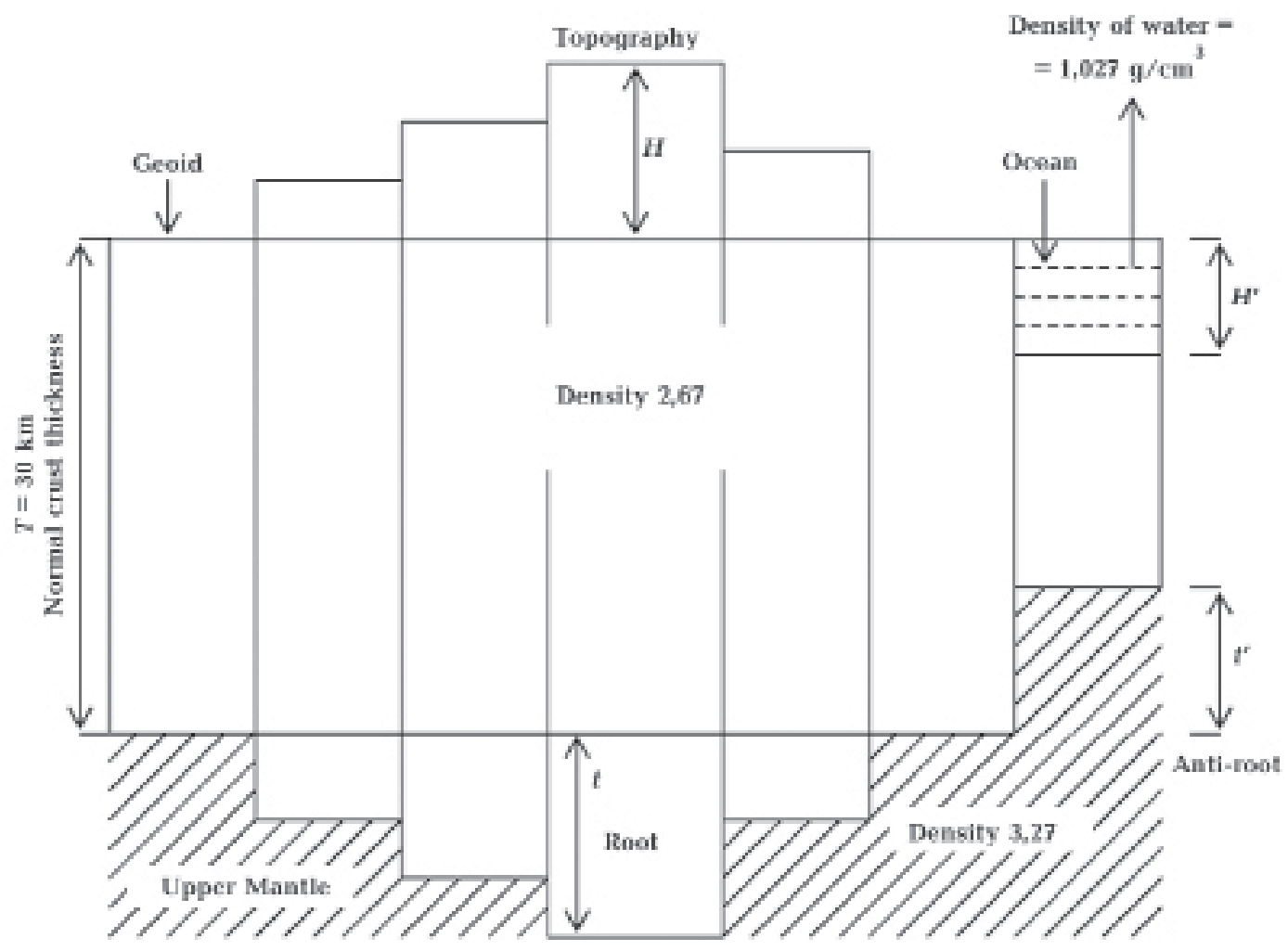

Fig. 2. Airy—Heiskanen isostatic model in planar approximation [llk, Witte, 2007] 2.2 Pratt—Hayford model (Planar and spherical approximation).

The corresponding free air gravity anomaly can be obtained from the anomalous potential as [Heiskanen, Moritz, 1967, p. 97].

$$
\begin{aligned}
\Delta g_{\mathrm{F}}=\frac{G M}{r^{2}} & \left(\sum _ { n = 2 } ^ { N } ( \frac { a } { r } ) ^ { n } ( n - 1 ) \sum _ { m = 0 } ^ { n } \left(\bar{C}_{n m} \cos m \lambda+\right.\right. \\
& \left.+\bar{S}_{n m} \sin m \lambda\right) \bar{P}_{m n} \sin \varphi,
\end{aligned}
$$

$\Delta g_{\mathrm{F}}$ - free air anomaly.

The Earth Gravitational Model EGM 2008 [Palvis et al., 2008] is complete to spherical harmonic degree and order 2159 and contains additional coefficients extending to degree 2190 and order 2159. The harmonic degree implies that short wavelength anomalous features can be studied which is relevant in the determination of the near surface mineral depth and its mass density distribution [Featherstone, 1997]. The free air anomaly derived from the spherical harmonic model is stated as follows:

\subsection{Isostatic Geoid Anomalies}

\subsubsection{Co-Geoid and Geoid undulations}

The geoid undulation $\mathrm{N}$ is the vertical separation between the geoid and the ellipsoid. Fig. 4 shows the geometric separate of the geoid and the co-geoid. In gravimetric geoid determination, the computed geoid does not match with the actual geoid. The difference between the actual geoid and the computed geoid is called the indirect effect.

The formula for computing co-geoid undulation from a 3D density model $\Delta \rho(x, y, z)$ is expressed as [Turcotte, Schubert, 1982]:

$$
N^{\mathrm{c}}=\frac{2 \pi G}{\gamma_{0}} \int_{H}^{T+t} z\left(\rho_{m}-\rho_{c r}\right) d z+\int_{-H}^{0} z \rho_{c r} d z
$$

$N^{\mathrm{c}}$ - co-geoid, $\gamma_{0}$ - normal gravity, $G$ - universal gravitational constant, $p_{m}$ - mantle density, $\rho_{\mathrm{cr}}-$ crustal density.

For Airy-Heiskanen compensation with depth of the normal $T$, surface topography $H$ and the root 


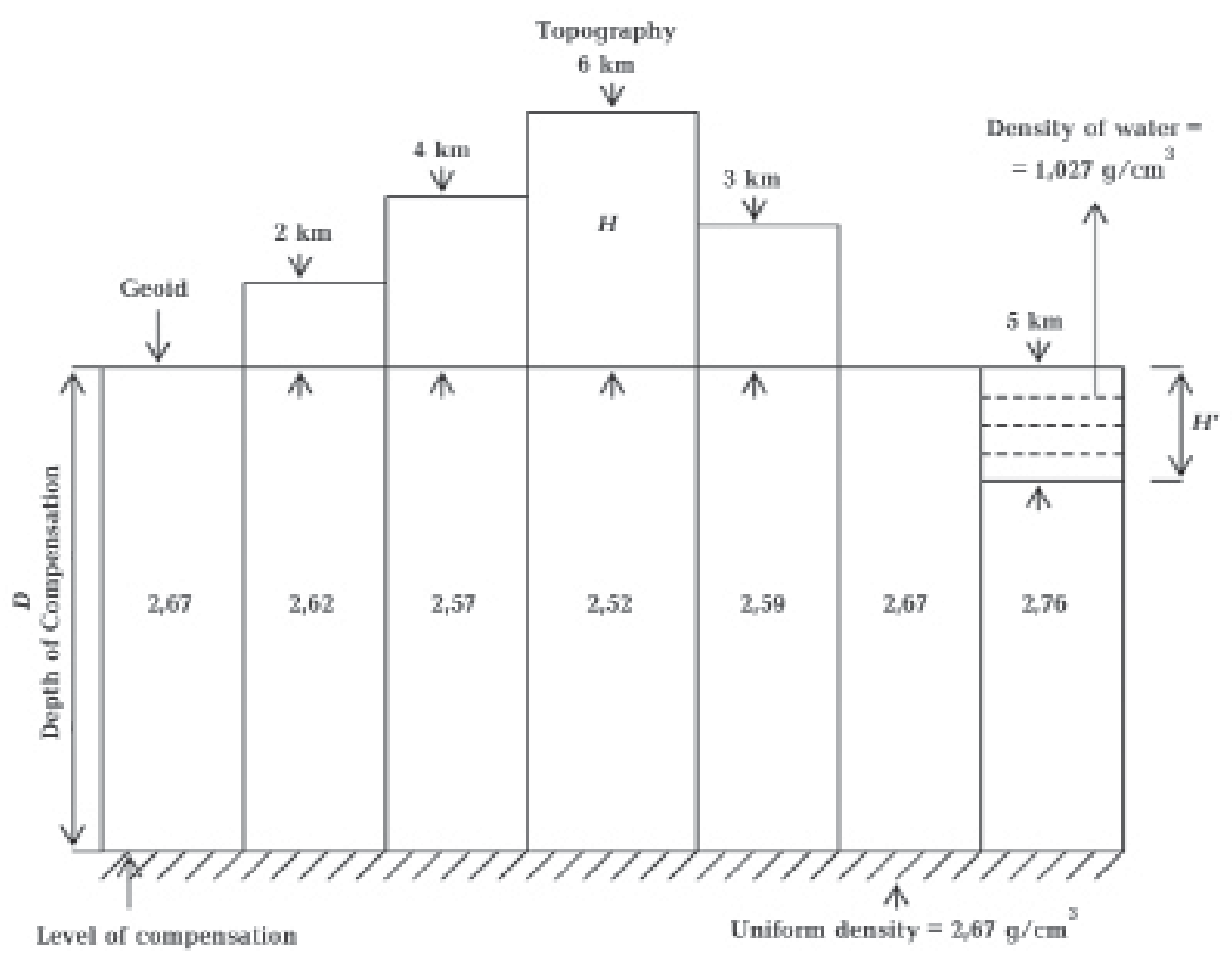

Fig. 3. Pratt—Hayford compensating model (constant density) in planar approximation [llk, Witte, 2007].

$t$. From Eq. 1, taking downward continuation, the co-geoidal undulation is given for planar approximation [Crovetto et al., 2008] as:

$$
N^{\mathrm{c}}=\frac{\pi G \rho_{\mathrm{cr}}}{\gamma_{0}}\left\{2 T H+\frac{\rho_{\mathrm{m}}}{\rho_{\mathrm{m}}-\rho_{\mathrm{cr}}} H^{2}\right\} .
$$

In the Airy-Heiskanen formula, we assume a perfect isostatic balance using $T=30 \mathrm{~km}$, density 2.67 and density contrast $\rho_{\mathrm{m}}-\rho_{\mathrm{cr}}=0.6 \mathrm{~g} / \mathrm{cm}^{3}$. For spherical approximation with respect to Eq. 2, it is derived as:

$$
N^{\mathrm{c}}=\frac{\pi G t}{\gamma_{0}} t+2 T\left(\rho_{\mathrm{m}}-\rho_{\mathrm{cr}}\right)
$$

$c_{m}$ - upper mantle density $\left(3.27 \mathrm{~g} / \mathrm{cm}^{3}\right)$.

In the use of Pratt-Hayford model for planar earth (Eq. 3), with depth compensation $D$ and normal density $\rho_{\text {cr }} H$ - elevation, the co-geoid undulation associated with positive topography is derived from Eq. 7 as:

$$
N^{\mathrm{c}}=\frac{\pi G \rho_{\mathrm{cr}}}{\gamma_{0}} D H
$$

For spherical approximation with respect to Eq. 4, it is derived from Eq. 7 as

$$
N^{\mathrm{c}}=\frac{\pi G}{\lambda_{0}}\left[D^{2}\left(\rho_{\mathrm{cr}}-\rho_{\mathrm{L}}\right)+\rho_{\mathrm{L}} H^{2}\right] .
$$

After computing the co-geoid undulation, the geoid undulation $N$ is computed by adding a number of additive corrections (which sum up as the indirect effects) to the co-geoid

$$
\begin{gathered}
N=N^{\mathrm{c}}+\delta N, \\
\delta N=\delta N_{\text {PITE }}+\delta N_{\Delta p}+\delta N_{\text {DWC }}
\end{gathered}
$$

$N$ - geoid undulation, $\delta N$ - total indirect effect, which must use the same density model as the gravity anomalies, $\delta N_{\Delta p}$ - lateral isostatic density anomaly indirect effect on the geoid, $\delta N_{\text {DWC }}-$ indirect effect due to downward continuation. The contribution of this effect cancels in their sum.

\subsubsection{Primary Indirect Terrain Effect}

The primary indirect topographical effect (PITE) is the separation between the geoid and the co-geoid caused by the condensation of the topography and the atmosphere 


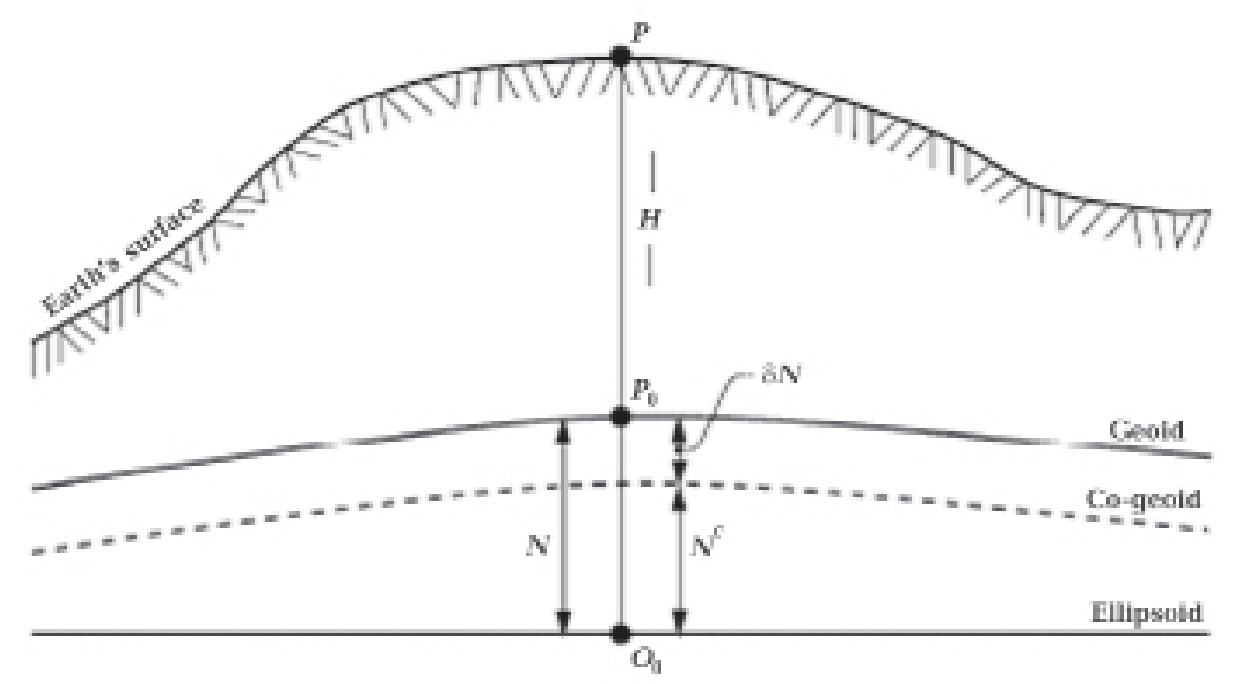

Fig. 4. The Relationship between geoid and co-geoid [Kuhn, 2003].

$$
\delta N_{\text {PITE }}=\frac{\delta V}{\gamma_{0}},
$$

$\delta V$ - change of potential at the geoid which depends on the reduction method used.

2.4.3 The Effect of Lateral Density Variation on the Geoid

Sjöberg [2004] showed that the total effect of the geoid due to the lateral density anomaly could be represented as a simple correction proportional to the lateral density anomaly and the elevation of the computation point square. The combined topographic effect on the geoid [Sjöberg, 2001; Kiahmehr, 2006b] including the zero and first degree terms is well approximated by

$$
\delta N_{\text {comb }}^{1}=\frac{2 \pi G \rho}{\gamma_{0}} H^{2},
$$

where $G$ - gravitational constant, $\rho=\rho(\theta, \lambda)$ is the laterally variable topographic density at the colatitude $(\theta)$, and longitude $(\lambda), H$ - height, $\gamma_{0}-$ normal gravity.

The lateral density variations indirect effect on geoid determination was computed using Eq. 14. If the density of the topography at the computational point is

$$
\rho=\rho_{\text {cr }}+\Delta \rho,
$$

where $\rho_{\text {cr }}$ is the standard density $\left(2.67 \mathrm{~g} / \mathrm{cm}^{3}\right), \Delta \rho(\varphi$, $\lambda$ ) is the lateral density anomaly with respect to the standard density. The total effect of $\Delta \rho$ on the geoid undulation becomes

$$
\delta N_{\Delta \rho}=\frac{2 \pi G \Delta \rho}{\gamma_{0}} H^{2} .
$$

For the Airy-Heiskanen model for geoid undulation computation, the lateral density variation indirect effect on the geoid for planar approximation with respect to Eq. 1 is given as

$$
\delta N_{\Delta \rho(\mathrm{AH})}=\frac{2 \pi G \rho_{\mathrm{cr}}}{\gamma_{0} t} H^{3} .
$$

Based on the concept above, the indirect effect in spherical approximation with respect to Eq. 2, is derived as

$$
\begin{gathered}
\delta N_{\Delta \rho(\mathrm{AH})}=\frac{2 \pi G \Delta \rho \mathrm{H}^{2}}{\gamma_{0}}= \\
=\frac{2 \pi G \rho_{\mathrm{cr}}}{\gamma_{0}}\left[\frac{(R+H)^{3}-R^{3}}{(R-T)^{3}}\right] H^{2} .
\end{gathered}
$$

From the Pratt-Hayford model for geoid undulation computation, the lateral isostatic density variation indirect effect for planar approximation on the geoid with respect to Eq. 3, is given as [Kiamehr, 2006b]

$$
\begin{gathered}
\rho_{\mathrm{L}}=\rho_{\mathrm{cr}}+\Delta \rho, \\
\delta N_{\Delta \rho(\mathrm{PH})}=\frac{2 \pi G \rho_{\mathrm{cr}}}{\gamma_{0}}\left(\frac{H^{3}}{D+H}\right) .
\end{gathered}
$$

The indirect effect in spherical approximation with respect to (Eq. 4), is derived as

$$
\delta N_{\Delta \rho(\mathrm{PH})}=\frac{2 \pi G\left(\rho_{\mathrm{cr}}-\rho_{\mathrm{L}}\right) H^{2}}{\gamma_{0}} .
$$

2.4.4 Geoid Undulations computations from isostatic models 
From the above formulations for the co-geoid, primary indirect terrain effect and lateral density variation indirect effect, the final expression for geoid undulation obtained from the isostatic models are:

$$
\begin{aligned}
& N_{\mathrm{AH}-\mathrm{Pl}}=\left[\frac{\pi G \rho_{\mathrm{cr}}}{\gamma_{0}}\left\{2 T H+\frac{\rho_{\mathrm{m}}}{\rho_{\mathrm{m}}-\rho_{\mathrm{cr}}} H^{2}\right\}\right]- \\
& -\left[2 \pi \frac{G \rho H d}{\gamma_{0}} \sin \left(\frac{\psi}{2}\right)\right]+\left[\frac{2 \pi G \rho_{\mathrm{cr}}}{\gamma_{0} t} H^{3}\right] \text {, } \\
& N_{\mathrm{AH}-\mathrm{Sp}}=\left[\frac{\pi G t}{\gamma_{0}}+2 T\left(\rho_{\mathrm{m}}-\rho_{\mathrm{cr}}\right)\right]- \\
& -\left[2 \pi \frac{G \rho H d}{\gamma_{0}} \sin \left(\frac{\psi}{2}\right)\right]+ \\
& +\left[\frac{2 \pi G \rho_{\mathrm{cr}}}{\gamma_{0}}\left[\frac{(R+H)^{3}-R^{3}}{(R-T)^{3}}\right] H^{2}\right] \\
& N_{\mathrm{PH}-\mathrm{Pl}}=\left[\frac{\pi G \rho_{\mathrm{cr}}}{\gamma_{0}} D H\right]-\left[2 \pi \frac{G \rho H d}{\gamma_{0}} \sin \left(\frac{\psi}{2}\right)\right]+ \\
& +\left[\frac{\hat{\mathrm{\imath}} \pi G \prod_{\mathrm{cr}}}{\gamma_{0}}\left(\frac{H^{3}}{D+H}\right)\right] \text {, } \\
& N_{\mathrm{PH}-\mathrm{Sp}}=\left[\frac{\pi G t}{\gamma_{0}}\left[D^{2}\left(\rho_{\mathrm{cr}}-\rho_{\mathrm{L}}\right)+\rho_{\mathrm{L}} H^{2}\right]\right]- \\
& -\left[2 \pi \frac{G \rho H d}{\gamma_{0}} \sin \left(\frac{\psi}{2}\right)\right]+ \\
& +\left[\frac{2 \pi G\left(\rho_{\mathrm{cr}}-\rho_{\mathrm{L}}\right) H^{2}}{\gamma_{0}}\right] \text {. }
\end{aligned}
$$

\subsection{Residual Geoid Undulations}

In order to reveal the short wavelength geoidal features which are assumed to reflect crustal and lithospheric structures, the long wavelength component of the geoid assumed to originate in the mantle is removed by the process termed detrending [Featherstone, 1997]. Residual geoid undulation is obtained as the difference between the geoid obtained from EGM 2008 model and the geoid undulations obtained from the isostatic models:

$$
\Delta N_{\mathrm{I}}=N_{\mathrm{EGM} 2008^{-}} N_{\mathrm{I}}
$$

where $\Delta N_{\mathrm{I}}$ - residual undulation for the various

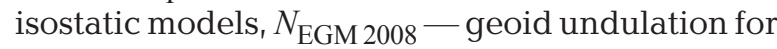
EGM 2008, $N_{\text {I }}$ - geoid undulation for the various isostatic models.
2.6 Geoid and Gravity Admittance Evaluation

Gravity and geoid anomalies reflect lateral heterogeneities in the earth's density structure. Because such anomalies often correlate with topography, it became a standard approach to use the relationship between bathymetry and the gravity or geoid to gain information about the subsurface density structure and the style of isostatic compensation of the topographic load assuming that compensation occurs on a regional basis. In the following, the geoid admittance (Geoid to Topographic Ratio) as a spectral function is calculated by [Keifer, Hager, 1991]:

$$
A_{\text {geoid }}(\lambda)=\frac{N(\lambda)}{H(\lambda)}
$$

$A_{\text {geoid }}(\lambda)$ - geoid admittance, $N(\lambda)$ - geoid undulation, $H(\lambda)$ - topography.

In relating the geoid undulations to free air gravity anomalies in the spectral domain, the following expression is used [Keifer, Hager, 1991]

$$
\begin{gathered}
\Delta g_{\mathrm{FA}}(\lambda)=\frac{2 \pi \gamma_{0} N(\lambda)}{\lambda}, \\
A_{\text {gravity }}(\lambda)=\frac{\Delta g_{\mathrm{FA}}(\lambda)}{H(\lambda)},
\end{gathered}
$$

where $A_{\text {gravity }}(\lambda)$ - gravity admittance, $\Delta g_{\mathrm{FA}}(\lambda)-$ free air anomaly.

In the case of the Airy-Heiskanen model, the topographic height is considered in terms of surface topography and mantle (dynamic topography) to determine the deep earth mass density anomalies [Bowin, 1983] and near-surface mass density distribution [Christou et al., 1989].

\subsection{Methodology}

The following data were utilized in the gravimetric geoid determination.

1. Digital terrain model (DTM) for modeling the shape of topography.

2. Digital Density Model (DDM) for modeling the spatial distribution of density in the topography and deeper masses. The information from seismic and well log observations were used to derive the density model.

3. Isostatic models for analytically modeling the Earth's outer masses.

4. EGM 2008 geoid undulation data.

5. Residual geoid obtained as difference between EGM 2008 and the local isostatic geoid.

Fig. 5 shows the flowchart for the geoid modeling and its geophysical analysis. 


\subsection{The Study Area and Gravity Data Acquisition}

Gongola basin of Northern Nigeria is one part of a series of Cretaceous and later rift basins in Central and West Africa whose origin is related to the opening of the South Atlantic [Obaje et al., 2006]. Many authors have noted that the Benue rift (which includes Gongola basin) have many features in common with other intra-continental East African rift such as Baikal rift and the Rio Graade rift, for example [Logatchev, 1993; Shemang et al., 2001; Ugbor et al., 2010]. These rift systems are associated with volcanism and regional up- lift. The basin contains thick sediment accumulations (mainly Cretaceous) in excess of $7 \mathrm{~km}$ in the North-Eastern part of the study area; deposited under varying environments. Seismic studies in the area have led the insight into the structure of the crust and mineral viability of the basin.

The gravitational data for this investigation is a set of Bouguer gravity and isostatic residual gravity anomalies observed at 1813 shot points with station interval of $500 \mathrm{~m}$ within Gongola basin.

4.0 Results

The following results shown in Fig. 6-10 il-

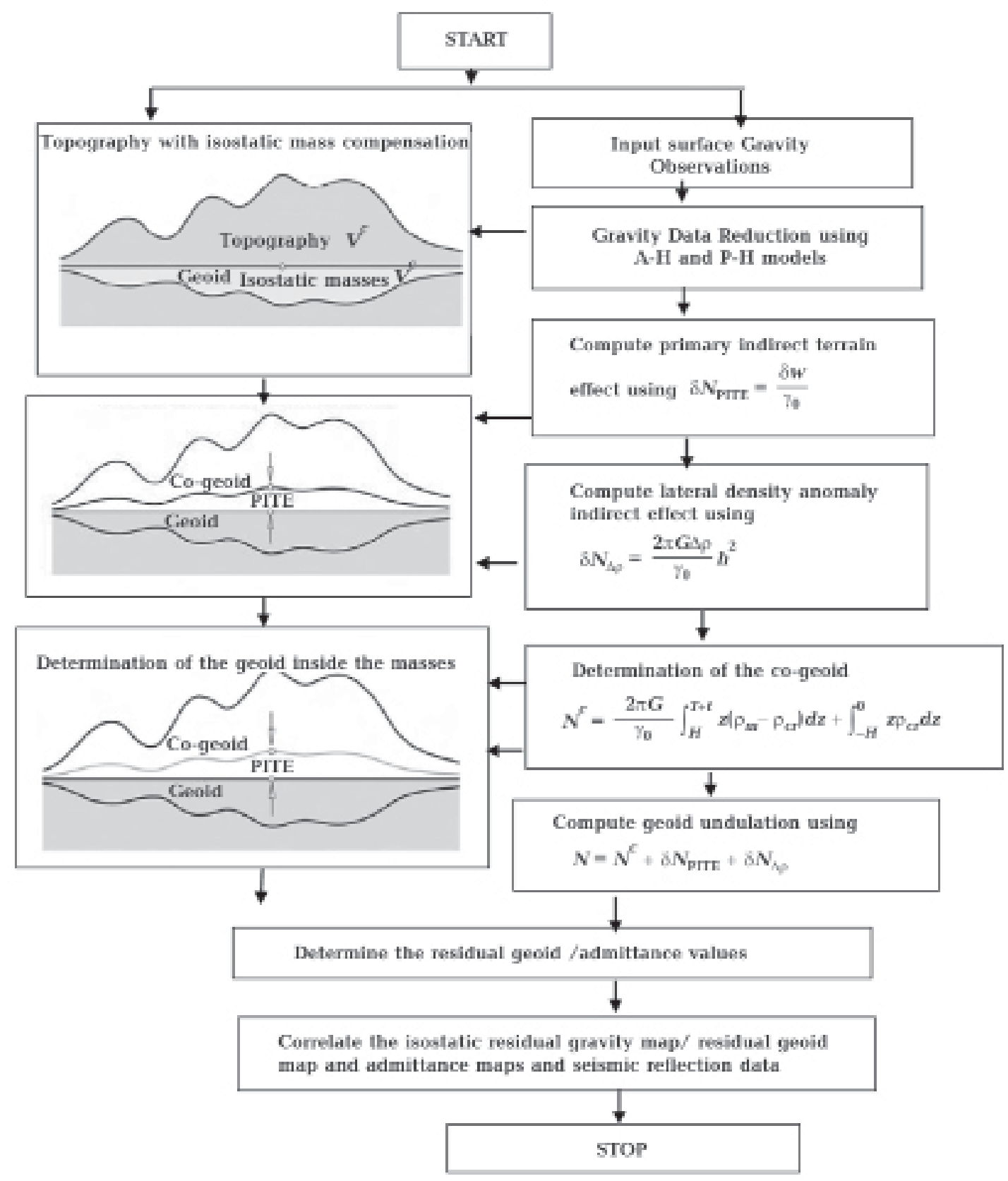

Fig. 5. Geoid Modeling and Geophysical Analysis Flow Chart (Modified from [llk, Witter, 2007]). 


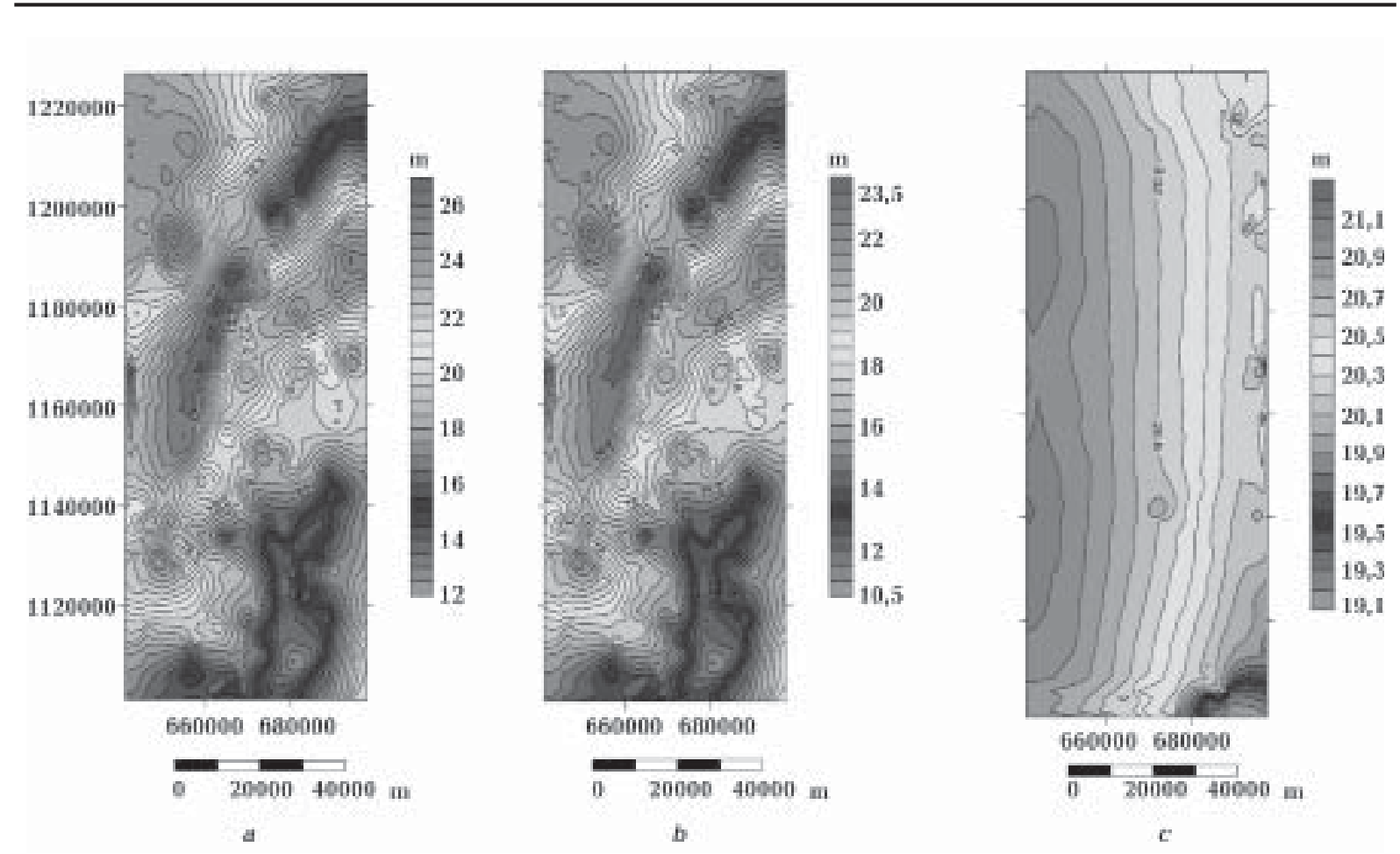

Fig. 6. Pratt—Hayford, Airy—Heiskanen and EGM 2008 geoid undulations.

lustrate the geoid and geophysical findings within the basin.

\subsection{Discussion}

4.1 Geoid and Residual Geoid Anomaly Maps

The spatial behavior of the geoid undulation for P-H and A-H and that of the EGM 2008 (Fig. 6) have similar characteristics with respect to the density variation in west-east direction; but differ in magnitude. However, the results from the $\mathrm{P}-\mathrm{H}$ spherical approximations are better than the other results in the planar and spherical approximations in terms of producing the minimum sum of squares of the residual geoid values (Fig. 7).

The isostatic geoid undulations are found to have long wavelength features between $4000<\lambda<8600 \mathrm{~m}$. These features of the geoid are due to density variations in the lower mantle and resulting deformations of the core mantle boundary and other boundaries in the mantle [Richards, Hager, 1984; Okiwelu et al., 2011]. The residual geoid undulations for the $\mathrm{P}-\mathrm{H}$ isostatic models range between $-7 \mathrm{~m}$ to $+11 \mathrm{~m}$ in the spherical approximation model. The negative residual geoid undulation values correspond with the region of less dense intrusive rocks in the SE, while the positive residual geoid values correspond to regions of high density subsurface intrusive rock deposits zones of the project area. The spatial behavior of the P-H isostatic residual gravity anomaly, the
P-H geoid undulation and the $\mathrm{P}-\mathrm{H}$ residual geoid (as shown in Fig. 7, $a, b$ ) correlates and this helps in the definition of the basin's subsurface density distribution. The large bias in the residual geoid undulation is based on the use of spherical harmonics coefficients in the EGM 2008 geoid model. Gravity disturbances [Heiskanen, Moritz, 1967], rather than gravity anomalies, are computed from the spherical harmonics so as to account for the masses between the reference ellipsoid and geoid [Kaban et al., 2004]. Geoid undulations are evaluated from the spherical harmonic coefficients at the surface of the ellipsoid, not taking into account the difference between height anomalies and geoid undulations [Heiskanen, Moritz, 1967] nor the effect on the geoid of the downward continuation of gravity from the surface [Sjöberg, 1998a]. Correlation exists in the geoid undulation between basement complex zones and the EGM 2008 geoid undulations. In comparison with the geology, there is a substantial agreement with respect to the sedimentary zones with large negative residual geoid undulations which is due to lateral density anomaly. This is due to the large density contrast which has a direct influence on the computed geoid. The area with high sedimentary thickness between $4 \mathrm{~km}$ and $7 \mathrm{~km}$ in the North-East has high density igneous intrusive rocks and as such, depicts positive residual geoid undulation values as shown in Fig. 7, c. The de- 


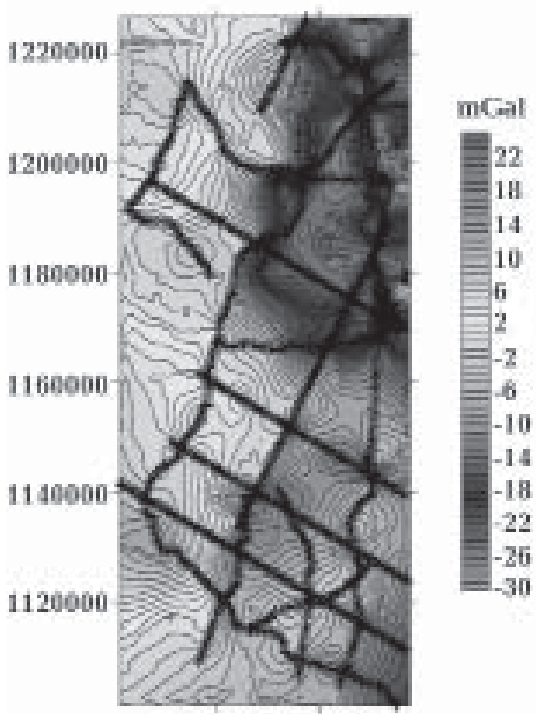

G60000 680000

$$
-2000040000 \mathrm{~m}
$$

a

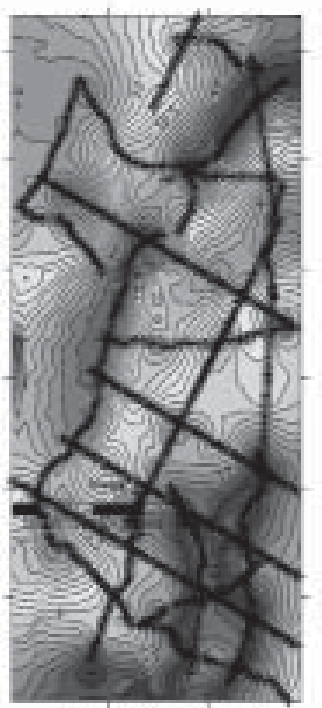

6tiooon Esuneo

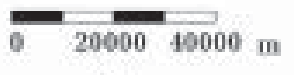

b

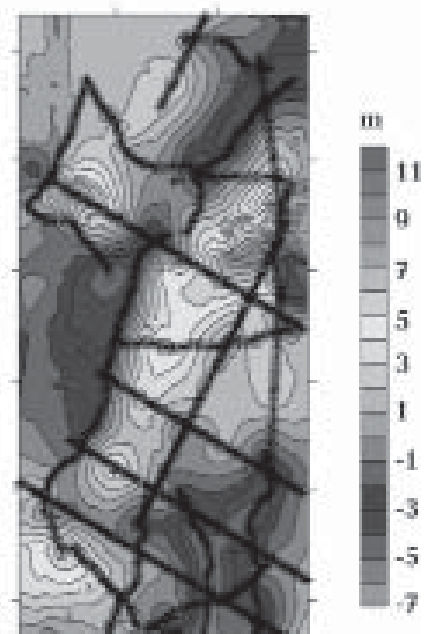

G60000 680000

(5) $20000 \quad 40000$ m

Fig. 7. Correlation of the isostatic residual gravity, geoid and residual geoid maps.

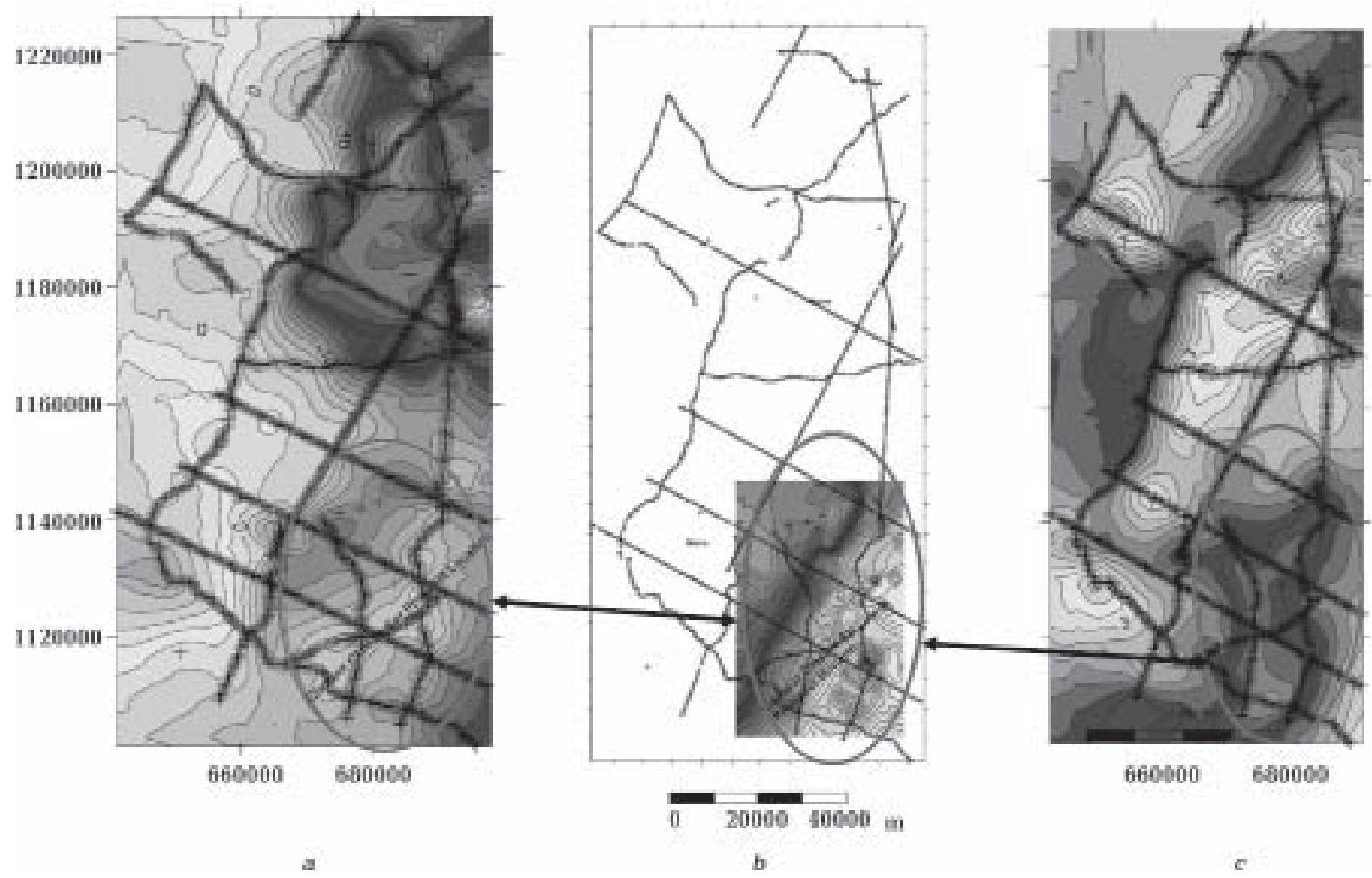

Fig. 8. Correlation of Isostatic Residual Gravity Anomaly, Seismic Horizon H4 depth map and Residual Geoid map.

crease in geoid undulations from west to east within the Gongola sedimentary basin shows the presence of depression in the NE and SE zones which is consistent with the evolution of the trough. The high geoid undulation transiting between the NE and SE (Fig. $6, a, b$ ) shows the presence of a ridge 

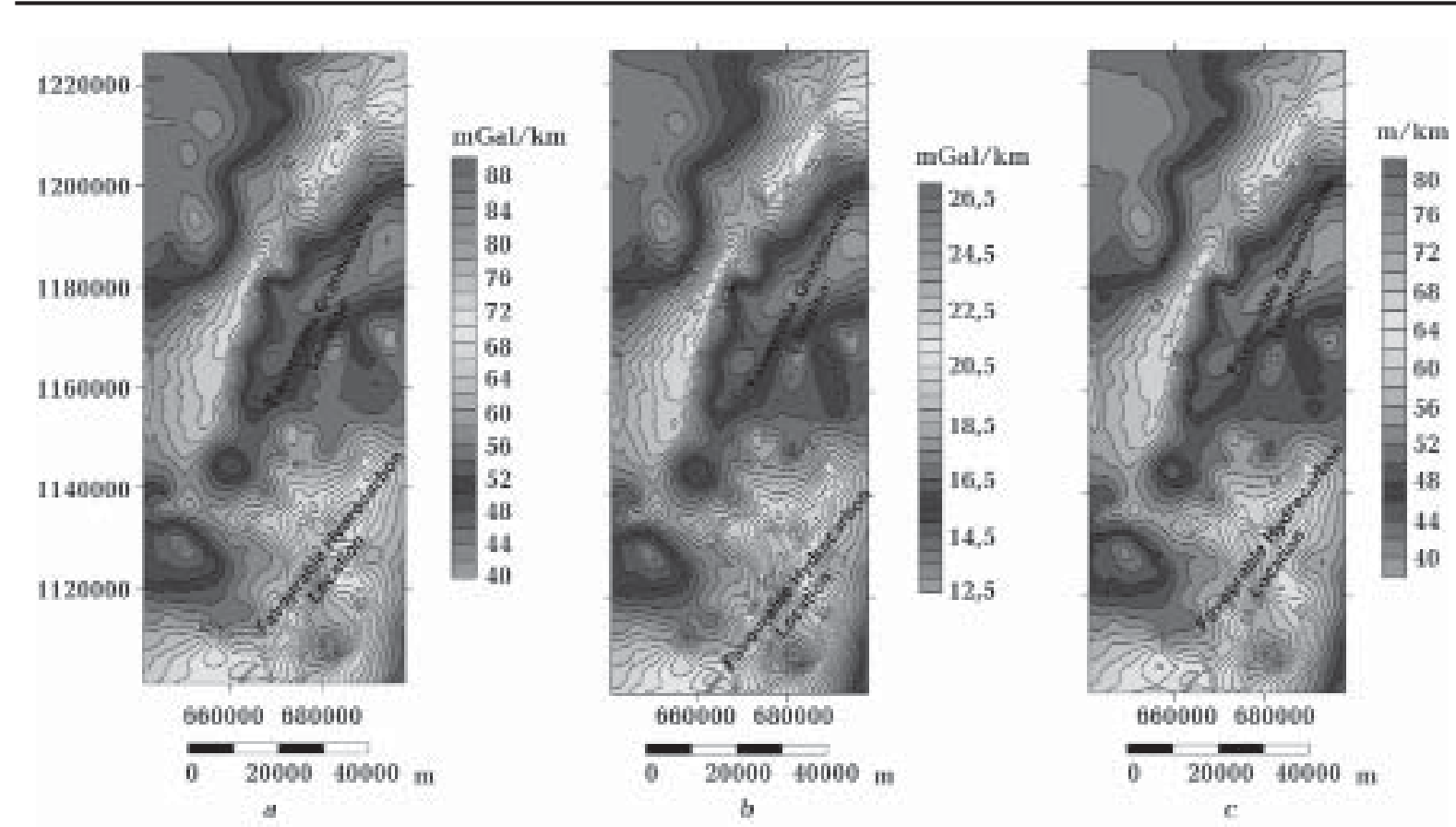

Fig. 9. Gravity and geoid admittance maps.

within this segment of the basin. The evolution of the Benue Trough is closely linked with the opening of the South Atlantic. Details on the sequence of events that led to its formation alongside other sedimentary basins in Nigeria are contained in the various literatures [King, 1950; Cratchley, Jones, 1965; Wright, 1976; Benkhelil, 1982; Whiteman, 1982]. It is a rift basin with plate dilation leading to the opening of the Gulf of Guinea [Benkhelil, 1989; Fairhead, Binks, 1991]. Benkhelil [1989] suggested that the evolution trough could also be as a result of tension resulting in a rift or wrench related fault basin. Mesozoic to Cenezoic magmatism has accompanied the evolution of the tectonic rift as it is scattered all over and throughout in the trough [Coulon et al., 1996; Abubakar et al., 2010]. A magmatic old rift was also suggested for the Gongola basin by [Shemang et al., 2001] while [Abubakar et al., 2010] suggested the evolution as a combination of mantle upwelling or rise of a mantle plume which resulted in crustal stretching and thinning and the emplacement of basic igneous material within the basement and sediment which resulted in rifting. The reflection seismic time/depth structural maps also define the SE zone as a zone with favourable structural geometry for hydrocarbon accumulation. Fig. 8 shows the correlation between the Pratt-Hayford isostatic residual gravity anomaly, the seismic depth map (at prospect horizon) and the Pratt-Hayford residual geoid undulation. The reflection seismic depth map corroborates the Pratt-Hayford geoid and residual geoid structural pattern and hence, the favourable locations for hydrocarbon accumulation (oval shapes in the maps) shown in the residual geoid are justified.

\subsection{Analysis of Geoid and Gravity Admittance} Maps

Short wavelength geoid provides information about the near surface features while long wavelength geoid with low degree $(n=6,7)$ provides information about the mass anomalies in the crust mantle zone [Bowin, 1985]. Their isostatic model gravity/geoid admittance were used to determine the mass anomalies in the crust mantle zone. The gravity admittance map (Fig. 9, a) from the Pratt Hayford isostatic model shows a uniform mass density distribution that corresponds with the result obtained from the mass density structure of EGM 2008 gravity admittance (Fig. 9, b). The mass anomalies from EGM 2008 geoid admittance corroborate with the gravity admittance structures from the isostatic model. The mass anomalies vary between 60 and $82 \mathrm{~m} / \mathrm{km}$ in the northeast while it varies between $38 \mathrm{~m} / \mathrm{km}$ and $60 \mathrm{~m} / \mathrm{km}$ in the southeast of the project area. Consequently, it could be inferred that the northeast zone has high density mass deposits while the southeast has low density mass deposits. The northeast is therefore a favourable location for solid minerals while the southeast is a favourable location for hydrocarbon deposits. The gravity/geoid admittance structures corrobo- 
rate the findings established in the geoid/residual geoid and seismic reflection studies.

\section{Conclusion}

Gongola basin geoid is primarily affected by the lateral density variation from the crust/mantle discontinuities. Based on this, the lateral density variation indirectly affected the accuracy of the geoid significantly by about $3 \mathrm{~cm}$.
The geoid and residual geoid undulations have shown in this research to corroborate the findings of the reflection seismic data in the determination of the lateral extent of known geological structures. This has also shown that the geoid can be used as a complementary method in the definition of the location and radial distribution of the geological structures for mineral and hydrocarbon exploration.

\title{
Gongola Basin Geoid Determination using Isostatic Models and Seismic Reflection Data and Geophysical Interpretation
}

\author{
(C) E. E. Epuh, J. B. Olaleye, O. G. Omogunloye, 2016
}

\begin{abstract}
The application of Stokes' formula to create geoid undulation requires no masses outside the geoid. Usually, a constant density of $2.67 \mathrm{~g} / \mathrm{cm}^{3}$ is used in the determination of the geoid which introduces error in the reduced gravity anomalies (Helmert's condensation) and consequently the geoid. In this paper, isostatic models of AiryHeiskanen and Pratt-Hayford were utilized in the determination of the geoid by considering the planar and spherical approximation models the indirect effect of the topographic lateral density variation on the geoid was computed as additive correction for the improvement of the accuracy of the computed geoid. Additional density information deduced from seismic and well log information were considered for the variable density computation. The geopotential geoid undulations were computed from the EGM 2008 model. The residual geoid was obtained by subtracting the local isostatic geoid from the geopential geoid. Geoid and gravity admittance studies were also carried out to complement the results from the residual geoid.

The planar and spherical approximation results showed similar characteristics; but a change in magnitude in both models. Our results suggest that the effects of topographic lateral density variations in geoid determination are significant and should be considered in rift basins. The geophysical analysis of the geoid results show that the north-east has positive residual geoid which indicates the presence of high density intrusive igneous rocks, while the south-east has negative residual geoid which indicates the dominant presence of low density sedimentary rocks. The results also show that the radial distribution of the anomalous mass obtained using the geoid/residual geoid anomaly uniquely matched that obtained using the seismic reflection data which inferred the presence of hydrocarbon accumulation in the southeast zone of the project area. The gravity and geoid admittance studies corroborated the residual geoid and seismic reflection results.
\end{abstract}

Key word: geoid undulation, Airy—Heiskanen model, Pratt—Hayford model, isostatic residual gravity anomaly, residual geoid undulation.

\section{References}

Abd-Elmotaal H., 1999. Comparison among different geoid solutions for the Egyptian south-western desert using FFT technique boll. Boll. Geofis. Teor. Appl. 40(3-4), 563-569.

Abd-Elmotaal H., Kuhtreiber N., 2003. Geoid determination using adapted reference field, seismic Moho depths and variable density contrast. J. Geodesy 77, $77-85$.

Abubakar Y. I., Umegu M. N., Ojo S. B., 2010. Evolution of Gongola Basin Upper Benue Trough Northeastern Nigeria. Asian J. Earth Sci. 3, 62-72.

Anderson E. G., 1979. The effect of topography on solution of Stokes' problem. Unisurv Report S-14, Uni- versity of New South Wales, Kensington, Australia, $252 \mathrm{p}$.

Benkhelil J., 1989. The Origin and evolution of the cretaceous Benue Trough (Nigeria). J. Afr. Earth Sci. $8,251-282$.

Bird D. E., 2001. Shear Margins: Continent-Ocean transforms and fracture zone boundaries. The Leading Edge 20(2), 150-159.

Bomford G., 1982. Geodesy. $5^{\text {th }}$ edn. Oxford: University Press.

Carter J. D., Barber W., Tait A. E., Jones J. P., 1963. The Geology of part of Adamawa, Bauchi and Borno 
Provinces in North Eastern Nigeria. Bull. Geol. Surv. Nigeria 30, 1-108.

Claessens S. A., 2003. A synthetic Earth model. Analysis, implementation, validation and application. Delft University Press. 61 p.

Cook F. A., Brown L. D., Oliver J. E., 1981. The Late Precambrian-Early. Paleozoic continental edge in the Appalachian Orogen. Am. J. Sci. 281, 993-1008.

Coulon C., Vida P., Dupuy C., Baudin P., Pupoff M., Maluski H., Hermite D., 1996. The Mesozoic to Early Cenezoic Magmatism of the Benue Trough (Nigeria): Geochemical Evidence for the Involvement of the St. Helena plume. J. Petrol. 37, 1341-1358.

Cratchley C. R., Jones G. P., 1965. An interpretation of the geology and gravity anomalies of the Benue Valley of Nigeria. Overseas geological survey. Geophysical Paper (1). 26 p.

Crovetto C. B., Introcaso A., 2008. Alternative gravimetric methodology for isostatic analyses: an example of Bolivian Andes. Boletin del Instituto de Fisiografia y Geologia 78(1-2), 1-11.

Engels J., Grafarend E. W., Sorcik P., 1995. The gravitational field of topographic isostatic masses and the hypothesis of mass compensation. Part I and II. Technical Report Department of Geodesy University, Stuttgart.

Featherstone W. E., 1992. A GPS controlled gravimetric determination of the geoid of the British Isles. D. Phil Thesis, Oxford University.

Featherstone W. E., Kirby J. F., Kearsley A. H. W., Gilliland J. R., Johnston G. M., Steed J., Forsberg R., Sideris M. G., 2001. The AUSgeoid98 geoid model of Australia: data treatment, computations and comparisons with GPS-levelling data. J. Geodesy $75,313-330$.

Forsberg $R ., 1984$. A study of terrain reductions, density anomalies and geophysical inversion methods in gravity field modeling. Department of Geodetic Science and Surveying. Report 355. The Ohio State University, Columbus.

Forsberg R., Sideris M. G., 1993. Geoid computations by multi-band spherical FFT approach. Manuscr. Geod. 18, 82-90.

Fraser D., Pagiatakis S. D., Goodacre A. K., 1998. Insitu rock density and terrain corrections to gravity observations. Proc. of the $12^{\text {th }}$ Annual Symposium on Geographic Information Systems, Toronto 6-9 April 1998. P. $357-360$

Heck B., 1992. Some remarks on the determination of the geoid in the framework of the internal geodetic boundary value problem. In: First continental workshop on the geoid in Europe. Research Institute of Geodesy, Topography and Cartography, Prague. P. $458-471$.

Heck B., Wild F., 2005. Topographic and isostatic reductions in Satellite Gravity Gradiometry based on a generalized condensation model. In: A Window on the Future of Geodesy, International Association of Geodesy Symposia. Vol. 128. Berlin, Heidelberg, New York: Springer, P. 294-299.

Heiskanen W. A., Moritz H., 1967. Physical geodesy. San Francisco: W. H. Freeman. Institute of Physical Geodesy. 364 p.

Heiskanen W. A., Vening Meinesz F. A., 1958. The Earth and its gravity field. New York: McGraw-Hill Book Company, Inc. $470 \mathrm{p}$.

Huang J., Vanicek P., Pagiatakis S., Brink W., 2001. Effect of topographical mass density variation on gravity and geoid in the Canadian Rocky Mountains. $J$. Geodesy 74, 805-815.

Hunegnaw A., 2001. The effect of lateral density variation on local geoid determination. Proc. IAG 2001 Scientific Assembly, Budapest, Hungary.

Ilk K. H., Witte B., 2007. The Use of Topographic-Isostatic Mass Information in Geodetic Applications. Inaugural Lecture. Institute of Geodesy and Geoinformation, University of Bonn, Germany.

Isioye O. A., Olaleye J. B., Youngu R., Aleem K. F., 2011. Modelling orthometric Heights from GPS-Leveling Observations an Global Gravity Model (EGM 2008) for Rivers State, Nigeria. Nigerian Journal of Surveying and Geoinformatics 3(2), 56-69.

Kaban M. K., Schwintzer P., Reigber C. H., 2004. A new isostatic model of the lithosphere and gravity field. J. Geodesy 78, 368-385.

Kiamehr R., 2006a. A strategy for determining the regional geoid in developing countries by combining limited ground data with satellite-based global geopotential and topographical models: a case study of Iran. J. Geodyn. 79(10-11), 602-612.

Kiamehr R., 2006b. The impact of lateral density variation model in the determination of precise gravimetric geoid in mountainous areas: a case study of Iran. Geophys. J. Int. 67, 521-527. doi:10.1111/j.1365246X.2006.03143.x.

Kiamehr R., Sjöberg L. E., 2005. Effect of the SRTM global DEM in the determination of a high-resolution geoid model of Iran. J. Geodyn. 79(9), 540—551.

Kuhn M., 2000. Density modeling for geoid determination. GGG2000, July 31-August 4, 2000, Alberta , Canada. 
Kuhn M., 2003. Geoid Determination with density hypotheses from isostatic models and geological information. J. Geodesy 77, 50-65/

Kuhtreiber N., 1998. Precise geoid determination using a density variation model. Phys. Chem. Earth 23(1), $59-63$.

Logatcher N. A., 1993. History of Geodynamics of Baikal Rift (East Siberia): A Review. Bulletin due center de la recherche exploration production 17, 353-370.

Martinec Z., 1998. Boundary-value problems for gravimetric determination of a precise geoid. Lecture Notes in Earth Sciences, no. 73. Berlin, Heidelberg, New York: Springer.

Martinec Z., 1993. Effect of lateral density variations of topographical masses in view of improving geoid model accuracy over Canada. Final rep. under DSS contract No. 23244-2-4356/01-SS, Geodetic Survey of Ottawa.

Martinec Z., Vanicek P., 1994. The indirect effect of Stokes-Helmert's technique for a spherical approximation of the geoid. Manuscr. Geod. 18, 417-421.

Martinec Z., Vanicek P., Mainville A., Veronneau M. 1995. The effect of lake water on geoidal height. Manuscr. Geod. 20, 199-203.

Moritz H., 1965. The boundary value problem of physical geodesy. Publication of the Isostatic Institute of the IAG, no. 50, Helsinki.

Moritz H., 1990. The figure of the Earth: theoretical geodesy and the Earth's interior. Karlsruche: Herbert Wichmann, $292 \mathrm{p}$.

Nettleton 1. L., 1971. Elementary gravity and magnetic for geologists and seismologists. Society of Exploration Geophysicists (SEG), Tulsa, Oklahoma, USA, $121 \mathrm{p}$.

Nwilo P. C., Opaluwa Y. D., Adejare Q. A., Ayodele E. G., Ayeni A. M., 2009. Local Geoid Modeling of Lagos island Area using Geometrical Interpolation Method. Nigeria Journal of Surveying and Geoinformatics 2(2), 68-82.

Obaje N. G., Attah D. O., Opeloye S. A., Moumouni A. 2006. Geochemical Evaluation of the Hydrocarbon Prospects of Sedimentary Basins in Northern Nigeria. Geochem. J. 40, 227-243.

Okereke C. S., 1988. Contrasting modes of rifting: The Benue Trough and Cameroon volcanic lines, West Africa. Tectonics 7(4), 775-784.

Okiwelu A., Okwueze C., Okereke C., Osazuwa I., 2010. Crustal Structure and Tectonics of the Calabar Flank, West Africa, based on Residual Gravity Interpretation. Eur. J. Soc. Sci. Res. 42(2), 195-203.
Okiwelu A. A., Okwueze E. E., Ude I. O., 2011. Determination of Nigerian Geoidal Undulation from Spherical Harmonic Analysis. Appl. Phys. Res. 3(1), 8-14.

Osazuwa I. B., Adeniyi O. O., Ojo J. B., 1992. A gravity study of the older granites suite in the Zaria Area of Kaduna State. Nigerian Journal of Mining and Geology 28(2), 231-236.

Pagiatakis S. D., Armenakis C., 1998. Gravimetric geoid modelling with GPS. Int. Geoid Serv. Bull. 8, 105-112

Pagiatakis S. D., Fraser D., McEwen K., Goodacre A. K., Veronneau M., 1999. Topographic mass density and gravimetric geoid modeling. Boll. Geofis. Teor. Appl. 40, 189-194.

Pratt J. H., 1855. On the attraction of the Himalaya Mountains, and of the elevated regions beyond them upon the plumb-line in India. Phil. Trans. Roy. Soc. London 145, 53-100.

Rummel R., Rapp R. H., Sunkel H., Tscherning C. C., 1988. Comparisons of global topographic-isostatic models to the Earth's observed gravity field. Reports of the Department of Geodetic Science and Surveying No. 388, Ohio State University, Columbus, Ohio.

Shemang E. M., Ajayi C. O., Jacoby W. R., 2001. A magnetic failed rift beneath the Gongola arm of the Upper Benue Trough, Nigeria? J. Geodyn. 32(3), 355-371.

Sideris M., 1996. International tests of the new GSFC/ DMA Geopotential Models. Gravity, Geoid and Marine Geodesy. International Association of Geodesy Symposia (Tokyo) 117, 478-485.

Sjöberg L. E., 2004. The effect on the geoid of lateral topographic density variations. J. Geodesy 78, 34-39.

Sjöberg L. E., 1998a. The exterior Airy/Heiskanen topographic-isostatic gravity potential, anomaly and the effect of analytical continuation in Stokes' formula. J. Geodesy 72, 654-662.

Sjöberg L. E., 2001. Topographic and atmospheric corrections of the gravimetric geoid determination with special emphasis of the effects of degrees zero and one. J. Geodesy 75, 283-290.

Sjöberg L. E., 1998b. On the Pratt and Airy models of isostatic geoid undulations. J. Geodyn. 26(1), 137-147.

Sun $W$., 2002. A formula for gravimetric terrain corrections using powers of topographic height. J. Geodesy 76(8), 399-406.

Sun W., Murata I., 1994. Divergence of high-degree harmonic solutions of a rotating elliptical Earth. Geophys. J. Int. 118, 269-271.

Sunkel H., 1985. An isostatic Earth model. Rep. 367, De- 
partment of Geodetic Science and Surveying, The Ohio State University, Columbus.

Tsoulis D., 2001. A comparison between the Airy-Heiskanen and the Pratt-Hayford isostatic models for the computation of potential harmonic coefficients. $J$. Geodesy 74(9), 637-643.

Tsoulis D., Tziavos I. N., 2003. A comparison of some existing methods for the computation of terrain corrections in local gravity field modelling. Gravity and Geoid 2002. Ziti-Publishing Thessaloniki, P. $156-16$.

Tziavos I. N., Featherstone W. E., 2000. First results of using digital density data in gravimetric geoids computation in Australia. IAG Symposia, GGG2000. Vol. 123. Berlin, Heidelberg: Springer Verlag, P. $335-340$.

Tziavos I. N., Sideris M. G., Sunkel H., 1996. The effect of surface density variation on terrain modeling- a case study in Austria. Proc. EGS Society General Assembly. The Hague, The Netherlands, May, 1996. Report of the Finnish Geodetic Institute. P. 99-110.

Turcotte D. L., Schubert G., 1982. Geodynamics. Applications of continuum physics to geological problems. New York: John Wiley \& Sons Ed., 450 p.

Ugbor D. O., Okeke F. N., 2010. Geophysical investigation in the lower Benue Trough of Nigeria using gravity method. Int. J. Phys. Sci. 5(11), 1757-1769.

Vanicek P., Huang J., Brink W., Novak P., 1998. Prelimi- nary investigation of the effect of topographic mass density variations on gravity and geoid in the Canadian Rocky Mountains. Progress report on contract "Theoretical and practical refinements of precise geoid determination methods». Geodetic Survey Division, Natural Resource Canada, Ottawa.

Vanicek P., Kleusberg A., 1987. The Canadian geoidstokesian approach. Manuscr. Geod. 12, 86-98.

Vanicek P., Martinec Z., 1994. The Stokes-Helmert scheme for the evaluation of precise geoid. Manuscr. Geod. 19, 119-128.

Vanicek P., Sun W., Ong P., Martinec Z., Najafi M., Vajda P., ter Horst B., 1996. Downward continuation of Helmert's gravity. J Geodesy 71, 21-34.

Wichiencharoen $C ., 1982$. The direct effects on the computation of geoid undulation. Rep. 336, Department of Geodetic Science and Surveying, The Ohio State University, Columbus.

Wild F., Heck B., 2004a. A comparison of different isostatic models applied to Satellite Gravity Gradiometry. Gravity, Geoid and Space Missions. International Association of Geodesy Symposia. Vol. 129. Berlin, Heidelberg, New York: Springer, P. 230-235.

Wild F., Heck B., 2004b. Effects of topographic and isostatic masses in Satellite Gravity Gradiometry. The Geoid and Oceanography. Proceedings of the Second International GOCE User Workshop Frascati/Italy, March 8-10, 2004. CD-ROM. 